Article

\title{
Corporate Sustainability in Bangladeshi Banks: Proactive or Reactive Ethical Behavior?
}

\author{
Olaf Weber *(D) and Rezaul Karim Chowdury \\ School of Environment, Enterprise and Development, University of Waterloo, Waterloo, ON N2L 3G1, Canada; \\ reza.cowdury@uwaterloo.ca \\ * Correspondence: oweber@uwaterloo.ca; Tel.: +1-519-4044-632
}

Received: 9 September 2020; Accepted: 25 September 2020; Published: 27 September 2020

check for updates

\begin{abstract}
The purpose of this study is to analyze the connection between the sustainability performance and financial performance of Bangladeshi banks to explore the impact of the Bangladesh Environmental Risk Management Guideline. We analyzed all 56 scheduled commercial banks that are currently operating in Bangladesh under the guidelines of the Central Bank of Bangladesh. Data for the sample has been collected from publicly available reports such as annual, sustainability, and corporate social responsibility (CSR) reports, disclosed sustainability and financial information on the banks' websites, including all bank branches, and data published from the Central Bank. Data has been analyzed using panel regression. Our results indicate that higher sustainability performance creates a higher financial performance, and that bigger banks perform better with regard to sustainability than smaller banks. The analysis did not find, however, that higher financial performance influences the sustainability performance of the banks positively. Consequently, this research contributes to the research on legitimacy-driven behavior of Bangladeshi banks. This behavior rather leads to a reactive adoption of sustainability activities instead of proactive behavior.
\end{abstract}

Keywords: sustainable banking; Bangladesh; legitimacy

\section{Introduction}

Recently, there has been an increasing number of calls for a more sustainable financial industry [1] that even motivated the Financial Stability Board of the G20 to establish a Task Force on Climate-Related Disclosure [2]. With the economic rise of many Asian countries, integrating sustainable finance into the financial industry of these countries is important to address environmental and social issues, such as environmental pollution [3] and inequality [4]. To address both organizational ethics and financial sector stability, several countries, among them China and Bangladesh, introduced financial industry sustainability policies in addition to voluntary codes of conduct implemented by the industry. These countries experience severe environmental issues, such as air and water pollution, that have significant effects on their population and therefore try to decrease lending to and investing in polluting industries as well as to increase financing of more environmentally friendly industries. Bangladesh Bank, for instance, introduced the Environmental Risk Management Guidelines (ERM) in 2011 [5] to engage the financial sector in green finance.

As financial sector sustainability regulations are relatively new, there is a lack of research about the effect of these policies on both the financial and the sustainability performance of the regulated industries. Furthermore, there is a gap in the knowledge about the connection between sustainability performance and the financial performance of banks in countries with such policies. Most of the studies published so far address the Chinese Green Credit Policy [6-10]. Those studies found a positive effect of green banking activities, such as green lending and the financial performance of the financial 
institutions. Studies addressing a South Asian country such as Bangladesh are sparse, and their results are controversial. However, they agree that sustainable banking, including corporate social responsibility (CSR) reporting, is in an early phase in Bangladesh [11-15].

Though ERM has been introduced in 2011, only a few banks in Bangladesh even adopted green banking guidelines at this time [16]. However, Ahmed and Ahmed [17], for instance, found that the sustainability performance of Bangladeshi banks has increased since then. Nevertheless, they did not find a correlation between their environmental and financial performance. Other studies that addressed the lending business, however, found that integrating sustainability criteria into the lending business decreases the number of default loans and consequently has a positive impact on a lender's financial performance [18]. Despite some research on sustainability in Bangladeshi banks, the question remains whether regulatory sustainability guidelines improve both the environmental and financial performance of the regulated banks.

We use legitimacy theory $[19,20]$ to explain why and how Bangladeshi banks adopt sustainability strategies and what the consequences are for their financial performance. The theory states that banks will adopt environmental regulations and increase their sustainability performance if there is outside pressure. Furthermore, the theory claims that external pressure is stronger for bigger banks than smaller banks. Finally, according to the theory, adopting guidelines because of legitimacy concerns will not lead to integration into the banks' strategies. Consequently, our three research questions are whether higher sustainability performance increases financial performance, whether better financial performance leads to higher sustainability performance, and whether bigger banks perform better with regard to sustainability than smaller banks.

To respond to the research questions, we analyzed all 56 regulated Bangladeshi banks between 2012 and 2016 based on their annual reports, CSR, or similar reports and on the information from their websites. In line with a study that addressed a similar question in China [8], an indicator system that consists of social and environmental sustainability indicators has been used to calculate a sustainability score (SS) for the banks. The score has been used as the independent variable to predict the financial performance of the banks as well as the dependent variable based on a lagged panel regression and Granger causality calculation [21].

The results of the study demonstrate that higher sustainability performance creates higher financial performance. However, the analysis did not find that higher financial performance influences the sustainability performance of the banks positively. Finally, we could show that bigger banks perform better with regard to sustainability than smaller banks.

Following legitimacy theory, we conclude that the analyzed banks are rather reactive concerning their sustainability strategy and that they mainly respond to the institutional pressure of Bangladesh Bank because of legitimacy purposes. Instead of integrating sustainability aspects into their core business to decrease risks and to increase the opportunities of green banking, and consequently increase their financial performance, banks rather react in a stakeholder-oriented fashion to keep their legitimacy. Consistent with legitimacy theory, they are biased towards activities favorable to stakeholders instead of a strategic sustainability approach.

The study contributes to legitimacy theory in sustainable banking and its financial consequences. It demonstrates that increased sustainability performance has a positive effect on the financial performance of banks, as intended by Bangladesh Bank's ERM, but that this information is not integrated into the banks' business strategies. Furthermore, the research contributes to legitimacy theory by adding knowledge about the legitimacy-driven behavior of South Asian banks. Moreover, our results contribute to theory by suggesting that legitimacy-driven behavior might not lead to strategic corporate sustainability that addresses the main societal issues in a proactive way.

The remainder of the paper describes the background literature and the theory, followed by the presentation of the sample and methods. Finally, we report the results of the study and finish with a discussion and conclusions. 


\section{Background}

Several studies have analyzed financial sustainability regulations and their impact on regulated banks. Most of these studies explore the impact of the Chinese Green Credit Guidelines. Some studies, however, also examine Bangladeshi banks with regard to their sustainability. In general, however, studies on this topic in South Asia are sparse. The following sections present an overview of empirical findings on banks and sustainability, financial sector sustainability regulations and policies, as well as theoretical findings on financial sector sustainability regulations and sustainability in banking.

Banks started integrating non-financial environmental and social aspects into their business during the 1980s. Firstly, they addressed internal environmental management [22], resulting in water, energy, and materials savings, as well as in lower emissions and high reputation [23]. As the second step, banks integrated environmental issues into lending, investing, asset management, and project finance [24]. Hence, they became CSR intermediaries [25] that influence the CSR of their clients, because higher corporate social performance (CSP) mitigates borrowers' financial risks [26]. Consequently, voluntary sustainability codes of conduct, such as the United Nations Environmental Program Financial Initiative (UNEPFI), the UN Principles for Responsible Investing (UNPRI), and the Equator Principles have been instigated [27].

Sustainability risks, such as those caused by climate change or negative environmental impacts of commercial borrowers or investees, have a significant influence on the financial risk of credit and investment portfolios. Consequently, they have to be managed thoroughly $[7,28]$. Therefore, many banks have implemented sustainable credit risk assessment procedures [29] and have been using environmental, social, and governance criteria to conduct responsible investments [30-32]. Some studies, however, suggest that the sustainability strategies of many banks are not substantially addressing their core business and the main societal issues [33].

For a long time, the pressure on the financial sector to perform well concerning the sustainability impact of their main products and services, such as lending and investing, has been lower than in many other industries (Weber et al., 2014). Studies have found, however, that environmental and sustainability reporting positively correlates with the size and the profitability of financial institutions $[14,34,35]$. Furthermore, the integration of environmental and sustainability issues into financial sector products and services has been increasing over time and has positive effects on the banks' financial performance (Scholtens, 2008a).

Consequently, one of the motivations for integrating sustainability into the banking business is the correlation with the financial performance of banks. Igbudu and Garanti [36] suggest that sustainable banking increases the banks' loyalty and corporate reputation, while a study in Germany identified a strong growth potential for social banking [37] and, therefore, a new market to tap into. Furthermore, studies found a positive connection between corporate social responsibility and financial performance in the banking sector [38,39], between sustainability, measured by the membership in the Dow Jones Sustainability Index (DJSI), and efficiency [40], as well as between responsible investing and financial returns [41,42]. However, Climent [43] found that ethical banks are less profitable than their conventional counterparts but that they have more substantial growth in their lending business.

Additionally, several studies suggest that banks are rather reactive and defensive concerning the incorporation of sustainability aspects into their core businesses [44,45]. Many of them focus on short-term results and do not integrate sustainability into their core business [46]. The need for a sustainability culture [47] to develop capabilities and to provide resources to improve corporate sustainability performance, however, is not only a phenomenon in the financial industry but in all sectors [48-51]. Consequently, financial sector sustainability regulations should take into account that banks might not have the necessary capabilities and resources to implement the regulations efficiently in a way that increases their financial performance.

Though heavily regulated compared with other industrial sectors, the financial sector's exposure to institutional pressure and regulations addressing sustainability [52], environmental, and societal risks $[53,54]$ is relatively small. Financial sector regulations focus mainly on risk-adjusted 
financial capital provisions, financial risks, and guaranteeing the stability of the financial industry. Newer approaches, however, also address the impact of the financial sector on sustainable development and risks for the stability of the financial industry caused by sustainability risks, such as climate change [55]. Mainly, regulations and policies addressing the impact of climate change on the financial sector are discussed, for instance, by the Task Force on Climate-related Financial Disclosures [56], but also in academia [57].

Financial sector sustainability regulations are implemented mainly for two reasons: (1) to increase green lending and investment and (2) to enhance the financial sector's financial stability $[7,18,58]$. The financial sector sustainability regulation that is most frequently discussed in academic publications is the Chinese Green Credit Policy, introduced by the China Banking Regulatory Commission in 2012 [6]. Whether the Chinese regulation has achieved its goals is controversial. Zhao and $\mathrm{Xu}$ [59] state that the Green Credit Policy will increase green lending and consequently contribute to sustainable development. Additionally, studies that analyzed the sustainability performance of Chinese banks found that banks with a higher green lending ratio and higher sustainability performance are exposed to lower risks [7-9]. Jiguang and Zhiqun [60] are more critical and claim that additional regulations and internationalization is needed to promote green finance, particularly carbon finance. Similarly, another study asks for better implementation mechanisms to guarantee the success of the green credit policy [10]. A study that addresses financial industry sustainability regulations in South America from a macro perspective, however, found a positive effect of these regulations on the financial stability of the financial industry [58].

The need to increase capabilities to become more sustainable, even in the presence of regulations, is emphasized by two studies. They suggest that environmental risk management practices have to be improved to avoid a trade-off between the sustainability performance of banks and their financial performance [61,62].

A study that addresses the implementation problem in Bangladesh came to a similar conclusion. Though there is a potential for sustainable banking to have positive effects on banks' financial performance, the necessary capabilities for sustainable banking, such as sustainable credit rating expertise and systems, are often missing [18]. Additionally, a study analyzing the situation in India suggests that the public sector banking industry addresses sustainability in a defensive and preventive way. The research indicates that banks adopt the regulatory norms but are not pro-active in addressing sustainable development in their business [45].

Positive impacts of sustainable banking on sustainable development, however, have been identified in a study analyzing Nigerian banks [63]. Similar to banks in China and Bangladesh, Nigerian banks are regulated through a sustainable banking policy overseen by the domestic banking regulator [55]. Hence, such regulations might change banks toward a direction where they contribute to sustainable development and reduce their financing of unsustainable businesses and projects [64].

Bangladesh Bank introduced the Environmental Risk Management (ERM) Guidelines for Banks and Financial Institutions in Bangladesh in 2011 [5]. Their goal is to incentivize banks to integrate environmental and social criteria into their credit risk management procedures and consequently to improve the environmental and social standards in Bangladesh's industries. ERM introduced guidelines and tools to improve the sustainability assessment as well as refinancing schemes for environmentally sustainable projects [18]. Consequently, if adopted, the policy should influence the environmental sustainability performance of Bangladeshi banks. Several studies assessing the corporate sustainability performance of Bangladesh companies and banks, however, suggest that corporate sustainability and corporate sustainability reporting is on a low level compared to other countries.

One of the earliest studies, as well as newer research on corporate sustainability reporting in Bangladesh, state that both the quantity and the quality of environmental disclosures are poor compared to those in many other countries [34,65], though many stakeholders in Bangladesh ask for transparent corporate reporting [66]. The reasons for the lack of disclosure are a shortage of resources, the exclusive 
focus on profit, lack of legal requirements, lack of awareness and capacity, poor sustainability performance, and the fear of bad publicity [67].

Additionally, studies on the sustainability reporting of Bangladeshi banks echo these results [12]. Khan and Islam [13], for instance, found that only a few Bangladeshi banks address all the criteria proposed by the Global Reporting Initiative. For example, only a few banks conduct environmental disclosure [68]. A reason for these results might be low stakeholder pressure, particularly from the general public [15]. Since 2010, however, funds allocated to green banking are increasing in Bangladesh, though the absolute value is still low [11]. Finally, public commercial banks in Bangladesh adopted the ERM guideline and increased their green lending [16] as well as their sustainability activities [69].

To close the gap in the literature about the adoption of green banking regulations in South Asia, the objective of our study is to analyze the sustainability performance of Bangladeshi banks, the connection between their sustainability performance and financial performance, and the influence of the banks' size and their sustainability performance.

\section{Theory}

The study is based on legitimacy theory [20]. In line with Suchman, we define legitimacy as a generalized perception or assumption that the actions of Bangladeshi banks are appropriate within the norms created by the regulator Bangladesh Bank. Related research found that legitimacy-based sustainability activities of firms are reactions to external pressure [70]. The emphasis here lies on reactive, meaning that corporations do not engage in sustainability activities as a proactive way to increase their business performance but as a reaction to stakeholder pressure or events. Consequently, activities decrease when pressure decreases [71].

Another implication based on legitimacy theory is that bigger institutions are more exposed to public pressure and therefore react more strongly [72]. In our study, we assume that bigger banks are more exposed to the influence of the public, including the regulator. Consequently, they conduct sustainability activities because of self-interest and normative approval [20]. Finally, in line with legitimacy theory, we hypothesize that banks report more about the environment than about social issues because the ERM mainly addresses environmental sustainability.

Sustainability activities triggered by legitimacy concerns, however, are not stable and do not address the core strategies and activities of banks but try to satisfy stakeholders. Therefore, we hypothesize that banks do not increase their sustainability activities even if they were able to improve their financial performance because of their sustainability activities. Hence, they do not follow a strategic corporate sustainability approach [73].

To summarize, our main hypotheses are (1) that Bangladeshi banks are reactive with regard to their sustainability activities, (2) that bigger banks perform a stronger reaction than smaller banks, (3) that Bangladeshi banks mainly focus on the environmental aspect of sustainability, and (4) that the financial success of sustainability activities does not lead to increased activities in the following year.

\section{Materials and Methods}

We analyzed all 56 scheduled commercial banks that are operating under the guidelines of the Central Bank of Bangladesh. Data for the sample was collected from publicly available reports, such as annual, sustainability, and CSR reports, disclosed sustainability and financial information on the banks' websites, including all bank branches, as well as data published by the Bangladesh Bank. We conducted a document analysis using NVIVO software. The keywords are in line with similar studies $[8,24]$ and are based on the criteria of the Global Reporting Initiative [74-76].

The sample consists of four types of banks, state-owned commercial banks (SOB), specialized development banks (SDB), private commercial banks (PCB), and foreign commercial banks (FCB) (see Table 1). Data was collected for the years between 2012 and 2016. The year 2016 was the year we found full disclosure for all banks in the sample at the time of gathering the data. The first year is the 
year of the implementation of the ERM guides. Only 22 out of the 56 banks, however, have published any information related to environmental, social, and sustainability aspects.

Table 1. List of banks in the sample.

\begin{tabular}{|c|c|}
\hline Bank Name & Type of Bank \\
\hline AB Bank Limited & Private Commercial Banks (PCB) \\
\hline Agrani Bank Limited & State-Owned Commercial Banks (SOCB) \\
\hline Al-Arafah Islami Bank Limited & Islamic Banks (IB) \\
\hline Bangladesh Commerce Bank Limited & Private Commercial Banks (PCB) \\
\hline Bangladesh Development Bank Limited & Specialized Banks (SDB) \\
\hline Bangladesh Krishi Bank & Specialized Banks (SDB) \\
\hline Bank Al-Falah Limited & Private Commercial Banks (PCB) \\
\hline Bank Asia Limited & Private Commercial Banks (PCB) \\
\hline BASIC Bank Limited & Specialized Banks (SDB) \\
\hline BRAC Bank Limited & Private Commercial Banks (PCB) \\
\hline Citibank N.A & Foreign Commercial Banks (FCB) \\
\hline Commercial Bank of Ceylon Limited & Foreign Commercial Banks (FCB) \\
\hline Dhaka Bank Limited & Private Commercial Banks (PCB) \\
\hline Dutch-Bangla Bank Limited & Private Commercial Banks (PCB) \\
\hline Eastern Bank Limited & Private Commercial Banks (PCB) \\
\hline EXIM Bank Limited & Islamic Banks (IB) \\
\hline First Security Islami Bank Limited & Islamic Banks (IB) \\
\hline Habib Bank Ltd. & Foreign Commercial Banks (FCB) \\
\hline ICB Islamic Bank Ltd. & Islamic Bank (IB) \\
\hline IFIC Bank Limited & Private Commercial Banks (PCB) \\
\hline Islami Bank Bangladesh Ltd & Islamic Banks (IB) \\
\hline Jamuna Bank Ltd & Private Commercial Banks (PCB) \\
\hline Janata Bank Limited & State-Owned Commercial Banks (SOCB) \\
\hline Meghna Bank Limited & Private Commercial Banks (PCB) \\
\hline Mercantile Bank Limited & Private Commercial Banks (PCB) \\
\hline Midland Bank Limited & Private Commercial Banks (PCB) \\
\hline Modhumoti Bank Ltd. & Private Commercial Banks (PCB) \\
\hline Mutual Trust Bank Limited & Private Commercial Banks (PCB) \\
\hline National Bank Limited & Private Commercial Banks (PCB) \\
\hline National Bank of Pakistan & Foreign Commercial Banks (FCB) \\
\hline National Credit \& Commerce Bank Ltd & Private Commercial Banks (PCB) \\
\hline NRB Bank Limited & Private Commercial Banks (PCB) \\
\hline NRB Commercial Bank Limited & Private Commercial Banks (PCB) \\
\hline NRB Global Bank Limited & Private Commercial Banks (PCB) \\
\hline One Bank Limited & Private Commercial Banks (PCB) \\
\hline Premier Bank Limited & Private Commercial Banks (PCB) \\
\hline Prime Bank Ltd & Private Commercial Banks (PCB) \\
\hline Pubali Bank Limited & State-Owned Commercial Banks (SOCB) \\
\hline Rajshahi Krishi Unnayan Bank & Specialized Banks (SB) \\
\hline Rupali Bank Limited & State-Owned Commercial Banks (SOCB) \\
\hline
\end{tabular}


Table 1. Cont.

\begin{tabular}{cc}
\hline Bank Name & \multicolumn{1}{c}{ Type of Bank } \\
\hline Shahjalal Islami Bank Limited & Islamic Banks (IB)) \\
\hline Social Islami Bank Ltd. & Islamic Banks (IB) \\
\hline Sonali Bank Limited & State-Owned Commercial Banks (SOCB) \\
\hline South Bangla Agriculture \& Com. Bank Limited & Private Commercial Banks (PCB) \\
\hline Southeast Bank Limited & Private Commercial Banks (PCB) \\
\hline Standard Bank Limited & Private Commercial Banks (PCB) \\
\hline Standard Chartered Bank & Foreign Commercial Banks (FCB) \\
\hline State Bank of India & Foreign Commercial Banks (FCB) \\
\hline The City Bank Ltd. & Private Commercial Banks (PCB) \\
\hline The Farmers Bank Ltd & Private Commercial Banks (PCB) \\
\hline The Hong Kong and Shanghai Banking Corp. Ltd. & Foreign Commercial Banks (FCB) \\
\hline Trust Bank Limited & Private Commercial Banks (PCB) \\
\hline Union Bank Limited & Private Commercial Banks (PCB) \\
\hline United Commercial Bank Limited & Private Commercial Banks (PCB) \\
\hline Uttara Bank Limited & Private Commercial Banks (PCB) \\
\hline Woori Bank & Foreign Commercial Banks (FCB)
\end{tabular}

Financial data was gathered from the banks' annual reports. We used total assets (TA), net profit after tax (NPAT), return on assets (ROA), and return on equity (ROE) as key financial accounting indicators. In line with [19], TA was used to measure the size of the banks. The other indicators have been used by similar studies that address the link between sustainability performance and financial performance in the banking sector (see, for instance, $[7,8,38,77]$ ).

The analysis of the sustainability performance was conducted in line with earlier studies that analyzed the sustainability performance of banks [8]. It is based on the framework of the Global Reporting Initiative [74]. The analysis assessed the presence of strategies, activities, products, and services in the categories of social sustainability, environmental sustainability, and green products and services. The latter were assessed because they are addressed by the ERM. If an indicator was mentioned, a bank achieved a value 1 for the indicator. Otherwise, it achieved the value 0 .

To analyze Granger causality [21], we used panel regression models with one-year lags for sustainability performance and financial performance, respectively. As the Hausman test [78] was significant, we used fixed-effects models. To control for accuracy of the regression, we used bootstrapping [79].

\section{Results}

We start by presenting the major financial and sustainability indicators of the banks in the sample, split by banking types (see Table 2). In line with Bangladesh Bank, we distinguished between conventional commercial banks, foreign commercial banks, Islamic banks, specialized banks, and state-owned commercial banks. 
Table 2. Financial and sustainability indicators split by bank type.

\begin{tabular}{|c|c|c|c|c|c|c|c|c|c|c|}
\hline $\begin{array}{l}\text { Bank } \\
\text { Type }\end{array}$ & & $\begin{array}{c}\text { Total } \\
\text { Assets }\end{array}$ & $\begin{array}{l}\text { Net } \\
\text { Profits }\end{array}$ & ROA & ROE & $\begin{array}{l}\text { NPL } \\
\text { Ratio }\end{array}$ & Social & Env. & Green & Sustainability \\
\hline \multirow{2}{*}{$\begin{array}{l}\text { Conventional } \\
\text { commercial }\end{array}$} & Average & $135,871.40$ & 1413.37 & $0.98 \%$ & $9.70 \%$ & $5.81 \%$ & 0.43 & 0.58 & 0.29 & 0.43 \\
\hline & Std. Dev. & $92,390.02$ & 1211.72 & $0.66 \%$ & $5.45 \%$ & $15.15 \%$ & 0.21 & 0.29 & 0.18 & 0.21 \\
\hline \multirow{2}{*}{$\begin{array}{c}\text { Foreign } \\
\text { commercial }\end{array}$} & Average & $79,485.69$ & 1726.81 & $1.37 \%$ & $8.24 \%$ & $5.26 \%$ & 0.30 & 0.66 & 0.12 & 0.36 \\
\hline & Std. Dev. & $77,342.22$ & 2964.60 & $6.62 \%$ & $10.13 \%$ & $4.44 \%$ & 0.12 & 0.19 & 0.12 & 0.12 \\
\hline \multirow{2}{*}{ Islamic bank } & Average & $213,850.90$ & 1797.99 & $0.55 \%$ & $7.77 \%$ & $11.65 \%$ & 0.42 & 0.61 & 0.22 & 0.42 \\
\hline & Std. Dev. & $208,579.00$ & 1587.95 & $1.76 \%$ & $7.80 \%$ & $23.23 \%$ & 0.17 & 0.25 & 0.11 & 0.17 \\
\hline \multirow{2}{*}{$\begin{array}{l}\text { Specialized } \\
\text { bank }\end{array}$} & Average & $135,491.60$ & -4580.30 & $-2.40 \%$ & $-6.83 \%$ & $22.90 \%$ & 0.37 & 0.43 & 0.08 & 0.29 \\
\hline & Std. Dev. & $82,663.93$ & 9151.55 & $4.19 \%$ & $8.61 \%$ & $6.70 \%$ & 0.03 & 0.26 & 0.12 & 0.12 \\
\hline \multirow{2}{*}{$\begin{array}{l}\text { State owned } \\
\text { commercial }\end{array}$} & Average & $307,341.60$ & -1172.75 & $0.20 \%$ & $-5.29 \%$ & $24.41 \%$ & 0.50 & 0.70 & 0.31 & 0.50 \\
\hline & Std. Dev. & $376,413.20$ & 7457.50 & $1.70 \%$ & $49.81 \%$ & $11.34 \%$ & 0.14 & 0.19 & 0.14 & 0.14 \\
\hline \multirow{2}{*}{ Total } & Average & $155,300.70$ & 1033.14 & $0.79 \%$ & $6.97 \%$ & $9.15 \%$ & 0.41 & 0.61 & 0.24 & 0.42 \\
\hline & Std. Dev. & $175,677.30$ & 3614.27 & $3.12 \%$ & $18.17 \%$ & $16.06 \%$ & 0.19 & 0.26 & 0.17 & 0.19 \\
\hline
\end{tabular}

Table 3 presents the percentage of banks that mentioned at least one of the respective sustainability indicators and the average per category. The results suggest an increase in disclosure over time and that environmental indicators are mentioned more often than social and green products and services indicators.

Table 3. Percentage of banks disclosing sustainability indicators between 2012 and 2016.

\begin{tabular}{|c|c|c|c|c|}
\hline Year & 2012 & 2013 & 2015 & 2016 \\
\hline \multicolumn{5}{|l|}{ Social Sustainability } \\
\hline Social Policies & $78.9 \%$ & $80.7 \%$ & $93.0 \%$ & $93.0 \%$ \\
\hline Social Management System & $38.6 \%$ & $40.4 \%$ & $49.1 \%$ & $49.1 \%$ \\
\hline Internal Social Management & $82.5 \%$ & $89.5 \%$ & $98.2 \%$ & $98.2 \%$ \\
\hline Social Credit Risk Assessment & $61.4 \%$ & $70.2 \%$ & $86.0 \%$ & $86.0 \%$ \\
\hline Social Loans & $54.4 \%$ & $57.9 \%$ & $77.2 \%$ & $77.2 \%$ \\
\hline Social Mortgages & $0.0 \%$ & $0.0 \%$ & $0.0 \%$ & $0.0 \%$ \\
\hline Social Funds & $7.0 \%$ & $10.5 \%$ & $22.8 \%$ & $22.8 \%$ \\
\hline Social Asset Management & $5.3 \%$ & $8.8 \%$ & $19.3 \%$ & $19.3 \%$ \\
\hline Social Bonds & $0.0 \%$ & $0.0 \%$ & $0.0 \%$ & $0.0 \%$ \\
\hline Social Microfinance Startup & $42.1 \%$ & $43.9 \%$ & $56.1 \%$ & $56.1 \%$ \\
\hline Social Project Finance Assessment & $0.0 \%$ & $1.8 \%$ & $7.0 \%$ & $7.0 \%$ \\
\hline Social Savings Products & $0.0 \%$ & $0.0 \%$ & $0.0 \%$ & $0.0 \%$ \\
\hline Social Financial Inclusion & $50.9 \%$ & $54.4 \%$ & $66.7 \%$ & $66.7 \%$ \\
\hline Stakeholder Engagement & $75.4 \%$ & $77.2 \%$ & $91.2 \%$ & $91.2 \%$ \\
\hline Social Community Building & $64.9 \%$ & $68.4 \%$ & $78.9 \%$ & $78.9 \%$ \\
\hline Social Investment Banking & $7.0 \%$ & $8.8 \%$ & $15.8 \%$ & $15.8 \%$ \\
\hline Other Social Products and Services & $1.8 \%$ & $1.8 \%$ & $10.5 \%$ & $10.5 \%$ \\
\hline Average Social Sustainability & $33.5 \%$ & $36.1 \%$ & $45.4 \%$ & $45.4 \%$ \\
\hline \multicolumn{5}{|l|}{ Environmental Sustainability } \\
\hline Environmental Policy & $61.4 \%$ & $66.7 \%$ & $86.0 \%$ & $86.0 \%$ \\
\hline Environmental Management System & $0.0 \%$ & $0.0 \%$ & $0.0 \%$ & $0.0 \%$ \\
\hline $\begin{array}{c}\text { Internal Environmental } \\
\text { Management }\end{array}$ & $66.7 \%$ & $73.7 \%$ & $89.5 \%$ & $89.5 \%$ \\
\hline
\end{tabular}


Table 3. Cont.

\begin{tabular}{|c|c|c|c|c|}
\hline Year & 2012 & 2013 & 2015 & 2016 \\
\hline $\begin{array}{c}\text { Environmental Credit Risk } \\
\text { Assessment }\end{array}$ & $64.9 \%$ & $73.7 \%$ & $87.7 \%$ & $87.7 \%$ \\
\hline $\begin{array}{l}\text { Average Environmental } \\
\text { Sustainability }\end{array}$ & $48.2 \%$ & $53.5 \%$ & $65.8 \%$ & $65.8 \%$ \\
\hline \multicolumn{5}{|l|}{ Green Products and Services } \\
\hline Green Industry Loans & $17.5 \%$ & $19.3 \%$ & $33.3 \%$ & $33.3 \%$ \\
\hline Green Mortgages & $0.0 \%$ & $0.0 \%$ & $0.0 \%$ & $0.0 \%$ \\
\hline Green Funds & $3.5 \%$ & $5.3 \%$ & $14.0 \%$ & $15.8 \%$ \\
\hline Green Indices & $0.0 \%$ & $0.0 \%$ & $0.0 \%$ & $0.0 \%$ \\
\hline Green Asset Management & $0.0 \%$ & $0.0 \%$ & $0.0 \%$ & $0.0 \%$ \\
\hline Green Bonds & $0.0 \%$ & $0.0 \%$ & $0.0 \%$ & $0.0 \%$ \\
\hline Green Microfinance & $3.5 \%$ & $3.5 \%$ & $15.8 \%$ & $17.5 \%$ \\
\hline Green Project Finance Assessment & $42.1 \%$ & $45.6 \%$ & $68.4 \%$ & $68.4 \%$ \\
\hline Green Savings Products & $0.0 \%$ & $0.0 \%$ & $0.0 \%$ & $0.0 \%$ \\
\hline Green Investment Banking & $0.0 \%$ & $1.8 \%$ & $14.0 \%$ & $15.8 \%$ \\
\hline Green Banking Reporting & $17.5 \%$ & $21.1 \%$ & $36.8 \%$ & $36.8 \%$ \\
\hline Green Branch Initiative & $15.8 \%$ & $15.8 \%$ & $22.8 \%$ & $22.8 \%$ \\
\hline Green Banking Department & $59.6 \%$ & $63.2 \%$ & $82.5 \%$ & $82.5 \%$ \\
\hline Green Office & $61.4 \%$ & $66.7 \%$ & $84.2 \%$ & $84.2 \%$ \\
\hline Green Central Bank Products & $50.9 \%$ & $52.6 \%$ & $71.9 \%$ & $71.9 \%$ \\
\hline Other Green Products and Services & $0.0 \%$ & $0.0 \%$ & $5.3 \%$ & $5.3 \%$ \\
\hline Average Green Product and Services & $17.0 \%$ & $18.4 \%$ & $28.1 \%$ & $28.4 \%$ \\
\hline
\end{tabular}

The three categories, social sustainability, environmental sustainability, and green products and services, were tested for homogeneity using Cronbach's alpha [80]. All three categories achieved a value higher than 0.8 , with $\alpha_{\text {social }}=0.87, \alpha_{\text {environment }}=0.87$, and $\alpha_{\text {green }}=0.85$. Consequently, based on the disclosure of the indicators, a sustainability score was calculated for each bank. First, we calculated the sum of the values for environmental, social, and green indicators. Then, the banks' results were divided by the maximum achievable value to standardize the values for the banks' performance in the respective category. Lastly, a sustainability score (SS) was calculated using the average of the environmental, social, and green scores. As a result, SS is an equally weighted combination of the environmental, social, and green products and services scores. The descriptive statistics of the categories and SS are presented in Table 4.

Table 4. Descriptive statistics of the sustainability indicators.

\begin{tabular}{cccccc}
\hline \multirow{2}{*}{ Year } & & $\begin{array}{c}\text { Social } \\
\text { Sustainability }\end{array}$ & $\begin{array}{c}\text { Environmental } \\
\text { Sustainability }\end{array}$ & $\begin{array}{c}\text { Green Products } \\
\text { and Services }\end{array}$ & $\begin{array}{c}\text { Sustainability } \\
\text { Score }\end{array}$ \\
\hline \multirow{3}{*}{2012} & Mean & 0.34 & 0.49 & 0.17 & 0.34 \\
\cline { 2 - 6 } & SD & 0.20 & 0.33 & 0.15 & 0.21 \\
\cline { 2 - 6 } & Skewness & -0.39 & -0.68 & 0.06 & -0.54 \\
\cline { 2 - 6 } & Kurtosis & 2.18 & 1.62 & 1.49 & 1.80 \\
\hline
\end{tabular}


Table 4. Cont.

\begin{tabular}{|c|c|c|c|c|c|}
\hline Year & & $\begin{array}{c}\text { Social } \\
\text { Sustainability }\end{array}$ & $\begin{array}{c}\text { Environmental } \\
\text { Sustainability }\end{array}$ & $\begin{array}{l}\text { Green Products } \\
\text { and Services }\end{array}$ & $\begin{array}{c}\text { Sustainability } \\
\text { Score }\end{array}$ \\
\hline \multirow{4}{*}{2013} & Mean & 0.37 & 0.54 & 0.19 & 0.37 \\
\hline & SD & 0.20 & 0.30 & 0.15 & 0.19 \\
\hline & Skewness & -0.32 & -1.03 & 0.04 & -0.72 \\
\hline & Kurtosis & 2.45 & 2.35 & 1.58 & 2.34 \\
\hline \multirow{4}{*}{2014} & Mean & 0.43 & 0.66 & 0.26 & 0.45 \\
\hline & SD & 0.16 & 0.21 & 0.16 & 0.15 \\
\hline & Skewness & -0.31 & -2.19 & 0.10 & -1.17 \\
\hline & Kurtosis & 3.43 & 6.71 & 2.67 & 4.63 \\
\hline \multirow{4}{*}{2015} & Mean & 0.46 & 0.67 & 0.29 & 0.47 \\
\hline & SD & 0.18 & 0.20 & 0.17 & 0.16 \\
\hline & Skewness & -0.01 & -2.51 & 0.09 & -1.01 \\
\hline & Kurtosis & 3.18 & 8.22 & 2.37 & 4.34 \\
\hline \multirow{4}{*}{2016} & Mean & 0.46 & 0.67 & 0.29 & 0.47 \\
\hline & SD & 0.18 & 0.20 & 0.18 & 0.16 \\
\hline & Skewness & -0.01 & -2.51 & 0.18 & -0.96 \\
\hline & Kurtosis & 3.18 & 8.22 & 2.40 & 4.28 \\
\hline \multirow{4}{*}{ Total } & Mean & 0.41 & 0.61 & 0.24 & 0.42 \\
\hline & SD & 0.19 & 0.26 & 0.17 & 0.19 \\
\hline & Skewness & -0.28 & -1.58 & 0.18 & -0.91 \\
\hline & Kurtosis & 3.05 & 3.88 & 2.39 & 3.19 \\
\hline
\end{tabular}

Table 5 presents the descriptive statistics for the financial indicators. In line with other studies [81], the indicators were transformed using the natural logarithm.

Table 5. Descriptive statistics for the financial indicators (natural logarithm).

\begin{tabular}{|c|c|c|c|c|c|}
\hline Year & & Total Assets & Net Profits & ROA & ROE \\
\hline & Mean & 11.39 & 6.62 & -4.70 & -2.68 \\
\hline \multirow[t]{4}{*}{2012} & SD & 1.16 & 1.57 & 0.97 & 1.12 \\
\hline & Skewness & -0.99 & -1.27 & -1.48 & -2.01 \\
\hline & Kurtosis & 3.81 & 4.51 & 6.11 & 7.46 \\
\hline & Mean & 11.06 & 6.40 & -4.75 & -2.89 \\
\hline \multirow[t]{4}{*}{2013} & SD & 1.51 & 1.94 & 0.82 & 1.43 \\
\hline & Skewness & -0.81 & -1.01 & -1.23 & -1.55 \\
\hline & Kurtosis & 3.09 & 3.12 & 4.52 & 4.88 \\
\hline & Mean & 11.30 & 6.61 & -4.70 & -2.87 \\
\hline \multirow[t]{4}{*}{2014} & SD & 1.34 & 1.80 & 0.91 & 1.48 \\
\hline & Skewness & -0.71 & -1.29 & -1.19 & -2.20 \\
\hline & Kurtosis & 2.99 & 4.43 & 5.24 & 8.61 \\
\hline & Mean & 11.47 & 6.66 & -4.69 & -2.66 \\
\hline \multirow[t]{3}{*}{2015} & SD & 1.26 & 1.70 & 1.33 & 1.17 \\
\hline & Skewness & -0.67 & -1.51 & -1.35 & -2.36 \\
\hline & Kurtosis & 2.77 & 5.33 & 5.87 & 8.94 \\
\hline
\end{tabular}


Table 5. Cont.

\begin{tabular}{cccccc}
\hline \multirow{2}{*}{ Year } & & Total Assets & Net Profits & ROA & ROE \\
\hline \multirow{3}{*}{2016} & Mean & 11.61 & 7.08 & -4.59 & -2.43 \\
\cline { 2 - 6 } & SD & 1.23 & 1.16 & 0.80 & 0.72 \\
\cline { 2 - 6 } & Skewness & -0.66 & -1.38 & -0.73 & -1.61 \\
\cline { 2 - 6 } & Kurtosis & 2.78 & 5.37 & 3.40 & 5.52 \\
\hline \multirow{3}{*}{ Total } & Mean & 11.37 & 6.68 & -4.69 & -2.71 \\
\cline { 2 - 6 } & SD & 1.31 & 1.66 & 0.98 & 1.23 \\
& Skewness & -0.81 & -1.38 & -1.36 & -2.21 \\
\cline { 2 - 6 } & Kurtosis & 3.29 & 4.73 & 6.62 & 8.76 \\
\hline
\end{tabular}

\section{Test Statistics}

To control for differences between government banks and other banks as well as between domestic banks and international banks, we conducted t-tests with SS as the dependent variable. We found a statistically significant difference between domestic and international banks with regard to their SS performance $(\mathrm{df}=278, \mathrm{t}=3.274, p=0.001)$. Domestic banks performed better with regard to the sustainability score than international banks $\left(\bar{x}_{\text {domestic }}=0.435, \bar{x}_{\text {international }}=0.338\right)$. The t-test for government-owned banks and other banks did not result in a statistically significant difference between these two groups $(\mathrm{df}=278, \mathrm{t}=-1.097, p=0.274)$.

Secondly, we tested the difference between the three categories: social sustainability, environmental sustainability, and green products and services. The results of the Hotelling Test [82] indicate a significant difference between the three categories $\left(\mathrm{T}^{2}=1871, \mathrm{~F}=619.2, p<0.0001\right)$. Environmental sustainability achieves the highest average, with social sustainability as the second-highest category, followed by green products and services $\left(\bar{x}_{\text {environment }}=0.61, \bar{x}_{\text {social }}=0.41, \bar{x}_{\text {green products }}=0.24\right)$.

As the next step, we analyzed the change in the sustainability performance SS as well as of the three sustainability sub-groups over time, as we assumed that the introduction of the ERM created a change with regard to the banks' sustainability performance. The change over time is presented in Figure 1, suggesting a slight increase in all three sustainability fields over time.

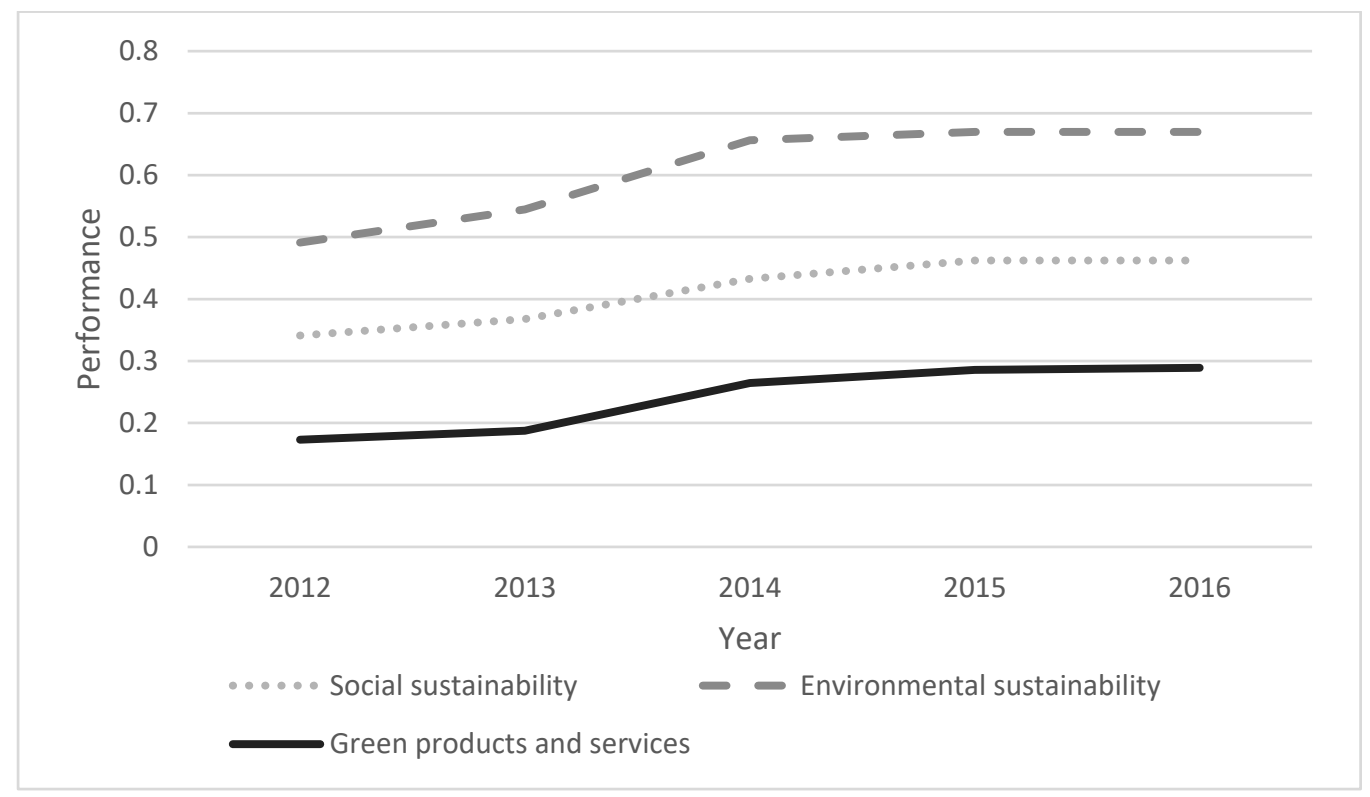

Figure 1. Change in the sustainability performance between 2012 and 2016. 
We tested the increase of the sustainability performance over time using an ANOVA for repeated measurement with the year and the banks as factors and the sustainability score as the dependent variable. The results of the ANOVA show that the change of the sustainability score over time is significant $(\mathrm{F}=24.86, \mathrm{df}=4, p<0.0001)$ and that there is a significant difference in the sustainability score between the banks $(\mathrm{F}=12.83, \mathrm{df}=55, p<0.0001)$. Additionally, the full model is significant $(\mathrm{F}=13.65, \mathrm{df}=59, p<0.0001)$ and explains 79 percent of the total variance.

In addition, Figure 1 shows that the development over time is very similar for all three categories. As tested above, the environmental sustainability category has the highest value before social sustainability and green products and services.

As the next step, we conducted a fixed-effects panel regression (see above for the Haussman test indicating fixed effects). The financial indicators and the sustainability score were used as independent and time-lagged dependent variables, respectively, to analyze cause and effect between the sustainability score and the financial performance using Granger causality (see Table 5). To control for accuracy, we used bootstrapping with 50 replications. The results of the one-year time lags are presented in Table 6. Two- and three-year time lags did not suggest different results but are based on fewer data.

Table 6. Panel regression with time lag with the sustainability score and financial indicators as independent and dependent variables.

\begin{tabular}{ccccc}
\hline $\begin{array}{c}\text { Dependent Variable } \\
\text { (1-Year Time Lag) }\end{array}$ & Independent Variable & Coefficient & $\mathbf{R}^{\mathbf{2}}$ & Sig. \\
\hline Sustainability Score & Total Assets & 0.063 & 0.13 & 0.018 \\
\hline Total Assets & Sustainability Score & 1.56 & 0.24 & $<0.00001$ \\
\hline Sustainability Score & Net Profit & 0.007 & 0.08 & 0.530 \\
\hline Net Profit & Sustainability Score & 3.25 & 0.19 & 0.0003 \\
\hline Sustainability Score & ROA & 0.012 & 0.0009 & 0.443 \\
\hline ROA & Sustainability Score & 1.78 & 0.0047 & 0.0080 \\
\hline Sustainability Score & ROE & -0.004 & 0.099 & 0.712 \\
\hline ROE & Sustainability Score & 2.13 & 0.20 & 0.0130 \\
\hline
\end{tabular}

The results show significant regressions for SS predicting the lagged financial indicators. The higher SS, the higher the financial indicators of the banks. The coefficients are positive and significant. Concerning the ability of the financial indicators to predict SS, only total assets, the indicator for the size of the banks, can predict the sustainability performance of a bank. There are no significant regressions for the other financial indicators as independent variables. Hence, the sustainability indicator is able to predict the financial performance, but financial indicators are not able to predict the sustainability performance of banks.

To test these findings for robustness, we used bootstrapping with 50 repetitions [79] and added the bank type as specified in Table 1 to the panel regressions. The results are presented in Table 7.

Table 7. Panel regression with time lag with the sustainability score and financial indicators as independent and dependent variables and the type of bank as a control variable.

\begin{tabular}{ccccc}
\hline $\begin{array}{c}\text { Dependent Variable } \\
\text { (Lagged) }\end{array}$ & $\begin{array}{c}\text { Independent } \\
\text { Variables }\end{array}$ & Coefficient & $\begin{array}{c}\text { Significance of } \\
\text { Coefficient }\end{array}$ & $\mathbf{R}^{\mathbf{2}}$ \\
\hline \multirow{2}{*}{ Total assets } & Sustainability & 1.65 & $<0.0001$ & $0.24^{* *}$ \\
\cline { 2 - 5 } & Type of bank & 0.05 & 0.721 & \\
\hline \multirow{2}{*}{ Net profit } & Sustainability & 3.42 & 0.001 & $0.21^{* *}$ \\
\cline { 2 - 5 } & Type of bank & -0.21 & 0.250 & \\
\hline
\end{tabular}


Table 7. Cont.

\begin{tabular}{|c|c|c|c|c|}
\hline $\begin{array}{c}\text { Dependent Variable } \\
\text { (Lagged) }\end{array}$ & $\begin{array}{l}\text { Independent } \\
\text { Variables }\end{array}$ & Coefficient & $\begin{array}{l}\text { Significance of } \\
\text { Coefficient }\end{array}$ & $\mathbf{R}^{2}$ \\
\hline \multirow{2}{*}{ ROA } & Sustainability & 1.37 & 0.035 & 0.03 \\
\hline & Type of bank & -0.16 & 0.195 & \\
\hline \multirow{2}{*}{ ROE } & Sustainability & 2.36 & 0.002 & $0.22 * *$ \\
\hline & Type of bank & -0.22 & 0.093 & \\
\hline \multirow{2}{*}{ NPL ratio } & Sustainability & 0.31 & 0.496 & 0.13 ** \\
\hline & Type of bank & 0.41 & $<0.001$ & \\
\hline \multirow{2}{*}{ Sustainability } & Total assets & 0.05 & $<0.0001$ & $0.14^{* *}$ \\
\hline & Type of bank & -0.01 & 0.636 & \\
\hline \multirow{2}{*}{ Sustainability } & Net profit & 0.01 & 0.211 & 0.07 \\
\hline & Type of bank & -0.01 & 0.773 & \\
\hline \multirow{2}{*}{ Sustainability } & ROA & 0.01 & 0.386 & 0.01 \\
\hline & Type of bank & 0.01 & 0.966 & \\
\hline \multirow{2}{*}{ Sustainability } & $\mathrm{ROE}$ & 0.01 & 0.372 & 0.10 \\
\hline & Type of bank & -0.01 & 0.969 & \\
\hline \multirow{2}{*}{ Sustainability } & NPL ratio & 0.03 & 0.073 & 0.04 \\
\hline & Type of bank & -0.02 & 0.293 & \\
\hline
\end{tabular}

The results presented in Table 7 indicate that the regression is robust. The same regression is significant after 50 bootstrapping repetitions. Furthermore, we did not find significant impacts of the type of bank on the prediction of the financial or the sustainability performance. The only significant coefficient for the type of bank is for the prediction of the nonperforming loan (NPL) ratio, because state-owned bank have a higher NPL ratio than other banks.

\section{Discussion}

This study analyzed the connection between sustainability performance and the financial performance of Bangladeshi banks. We used panel regressions with one-year time lags and both financial indicators and a sustainability score SS as dependent and independent lagged variables, respectively. The analysis of all scheduled commercial banks in Bangladesh found that a higher SS performance leads to better financial performance one year later. However, the study also suggests that better financial performance does not lead to higher sustainability performance in the following year. The results shine a light on organizational ethics and sustainability in the Bangladeshi banking industry.

Concerning the type of sustainability performance, our results indicate that all three, social sustainability, environmental sustainability, and green products and services, have been increasing in parallel over time. Environmental sustainability and green products and services, however, are not growing stronger than social sustainability, as could have been expected after the introduction of the ERM guidelines. Finally, we found that bigger banks perform better with regard to sustainability than smaller banks.

The following sections will discuss the results based on legitimacy theory [20]. According to this theory, the banks in our sample should react to institutional pressure reactively. They do not engage in sustainability activities proactively as would be predicted by strategic CSR [73].

The institutional pressure conducted through the ERM guidelines drives Bangladeshi banks to become more sustainable. They want to take the opportunity of the lower-cost capital provision by Bangladesh Bank and wish to avoid the adverse effects on their legitimacy of not reacting to the 
guidelines. This reaction increases the banks' sustainability performance and finally improves their financial performance, as found in many other studies [8,38].

The somewhat surprising result that increased financial performance does not improve sustainability performance can also be interpreted based on legitimacy theory. The banks in the sample react to outside factors and perform socially desired sustainability activities in return for approval of their business activities. However, they do not strategically internalize sustainability. If they did, the additional financial returns would lead to increased sustainability activities in the following year. In our study, however, we only found an impact of the sustainability performance on the lagged financial performance and not the other way around as, for instance, Waddock and Graves [83] report.

We also found a strong connection between the size of the banks, measured by their total assets, and their sustainability performance. This result is also in line with the legitimacy theory $[19,20]$, stating that bigger organizations are more exposed to public pressure and therefore invest more in their reputation [84] and stakeholder relations [85]. Additionally, Alberici and Querci [35] found that the quality of environmental activities of finance organizations increases with their size.

Similar to Islam and Kokubu [85], we found a general increase in all three types of sustainability activities. Again, legitimacy-based activities are rather reactive and general instead of addressing particular business activities and trying to improve their sustainability performance. Instead, the Bangladeshi banks address prevailing societal norms asking for corporate sustainability in general instead of specific actions that are connected to the banks' business. Therefore, we also found only a few banks that have implemented green financial products and services.

Concerning organizational ethics and sustainability in South Asia, the results suggest that regulatorily induced sustainability activities have a positive effect on Bangladeshi banks. Some studies in other world regions came to similar conclusions, for instance, in China $[7,86]$, but also in North America and Europe [87]. The missing connection between financial performance and sustainability performance at a later stage, however, seems to be specific for the Bangladesh sample. Waddock and Graves [83] established this connection and explained it with the institutional impact on both corporate sustainability performance and financial performance. Furthermore, they explain the positive impact of the sustainability performance on financial performance with the good management theory $[88,89]$. Hence, it seems that sustainability is not a part of good management in Bangladeshi banks yet and that the banks in the sample do not realize that they can create additional value through sustainability approaches [90].

Another interesting issue related to corporate sustainability in South Asia is that environmental sustainability is more often mentioned by the banks in the sample than social sustainability. However, topics such as inclusion and equality are a top priority in many South Asian countries [4,91]. The latter includes stakeholder engagement, community building, social inclusion, and so on. These issues should be at the core of sustainable banking in Bangladesh and other South Asian countries. However, an earlier study by Khan and Islam [13] suggests a similar result. Hence, it looks like there has not been much change in addressing social sustainability issues. As expected, the Bangladesh ERM did not improve this situation but only influenced the environmental performance of the banks. As Bangladeshi banks seem to have reputational motivations to integrate sustainability into their business, regulations addressing social sustainability might lead to an improvement in this regard.

Overall, it looks like the Bangladeshi banking sector has been increasing its sustainability performance between 2012 and 2016. One reason for this development might be the ERM that has been introduced in 2012. Because of the correlation between sustainability performance and financial performance, it not only contributes to improving the industry's environmental and social performance, but also to its financial performance. This finding is in line with the goals of the ERM and other financial industry sustainability regulations, such as the Chinese Green Credit Policy [7-10]. However, to increase the influence of the banking industry on sustainable development, a more long-term sustainability orientation is needed [92] that is supported by investments in sustainability performance. 


\section{Conclusions}

The results of our study contribute to legitimacy theory by showing that legitimacy is not only a driver for CSR reporting but also for CSR-related activities. The banks in our sample have implemented some sustainability activities because external stakeholders expect this behavior. However, the activities are reactive and not firmly connected to the banks' businesses. Green financial products and services, for instance, are not growing more than general social and environmental sustainability activities.

Our practical contribution addresses strategic sustainability in banking. The results suggest that banks should not only follow sustainability regulations but that they need to develop a strategy to benefit from the sustainable business approach. With regards to regulators, our results suggest that they should also offer training and tools to enable banks to build the necessary capacity to implement sustainability into their businesses.

Our research was limited with regard to data gathering. We only used publicly available data. Future research might use data from the banks that is gathered through interviews, portfolio analyses, as well as product and services analyses. Furthermore, the impacts of the sustainability performance on the environment and society should be analyzed in future research to explore the sustainability effects of financial sustainability regulations. This analysis should be done from a stakeholder perspective.

Author Contributions: Conceptualization, methodology, manuscript writing-review and editing: O.W.; investigation, resources, writing-original draft preparation: R.K.C. All authors have read and agreed to the published version of the manuscript.

Funding: This research received funding from the Social Sciences and Humanities Research Council (SSHRC).

Conflicts of Interest: The authors declare no conflict of interest.

\section{References}

1. Shrivastava, P. Finance and Management for the Anthropocene. Organ. Environ. 2019, 32, 26-40. [CrossRef]

2. Task Force on Climate-related Financial Disclosures. Recommendations of the Task Force on Climate-related Financial Disclosures; Task Force on Climate Related Disclosures: Basel, Switzerland, 2016; p. 74.

3. Hoque, A.; Clarke, A. Greening of industries in Bangladesh: Pollution prevention practices. J. Clean. Prod. 2013, 51, 47-56. [CrossRef]

4. Alamgir, F.; Cairns, G. Economic inequality of the badli workers of Bangladesh: Contested entitlements and a 'perpetually temporary'life-world. Hum. Relat. 2015, 68, 1131-1153. [CrossRef]

5. Bangladesh Bank. Environmental Risk Management (ERM) Guidelines for Banks and Financial Institutions in Bangladesh; Bangladesh Bank: Dhaka, Bangladesh, 2011; p. 43.

6. China Banking Regulatory Commission. Notice of the China Banking Regulatory Commission CBRC on Issuing the Green Credit Guidelines; Banking Regulatory Commission: Beijing, China, 2012; p. 6.

7. Cui, Y. The Impact of Green Lending on Credit Risk in China. Sustainability 2018, 10, 2008. [CrossRef]

8. Weber, O. Corporate sustainability and financial performance of Chinese banks. Sustain. Account. Manag. Policy J. 2017, 8, 358-385. [CrossRef]

9. Guan, R. The Higher Carbon Intensity of Loans, the Higher Non-Performing Loan Ratio: The Case of China. Sustainability 2017, 9, 667. [CrossRef]

10. Zhang, B.; Yang, Y.; Bi, J. Tracking the implementation of green credit policy in China: Top-down perspective and bottom-up reform. J. Environ. Manag. 2011, 92, 1321-1327. [CrossRef]

11. Islam, M.S.; Das, P.C. Green Banking practices in Bangladesh: A study on some selected Commercial Banks. IOSR J. Bus. Manag. 2013, 8, 39-44.

12. Khan, C.H.-U.-Z.; Halabi, A.K.; Samy, M. Corporate social responsibility (CSR) reporting: A study of selected banking companies in Bangladesh. Soc. Responsib. J. 2009, 5, 344-357. [CrossRef]

13. Khan, C.H.-U.-Z.; Islam, M.A.; Fatima, J.K.; Ahmed, K.; Khan, H.-U.-Z. Corporate sustainability reporting of major commercial banks in line with GRI: Bangladesh evidence. Soc. Responsib. J. 2011, 7, 347-362. [CrossRef]

14. Saha, A.K. Relationship between corporate social responsibility performance and disclosures: Commercial banks of Bangladesh. Soc. Responsib. J. 2019, 15, 451-468. [CrossRef] 
15. Sarker, H.F. Corporate Social Responsibility of Private Banks in Bangladesh: Expectations, Achievements and Challenges. J. Public Adm. Gov. 2012, 2, 176-187.

16. Ullah, M.M. Green Banking in Bangladesh-A Comparative Analysis. World Rev. Bus. Res. 2013, 3, 74-83.

17. Ahmed, S.P. The policy-led sustainability and financial performance linkage in the banking sector: Case of Bangladesh. Banks Bank Syst. 2019, 14, 89. [CrossRef]

18. Weber, O.; Hoque, A.; Islam, A.M. Incorporating environmental criteria into credit risk management in Bangladeshi banks. J. Sustain. Financ. Invest. 2015, 5, 1-15. [CrossRef]

19. Bansal, P. Evolving sustainability: A longitudinal study of corporate sustainable development. Strateg. Manag. J. 2005, 26, 187-218. [CrossRef]

20. Suchman, M.C. Managing Legitimacy: Strategic and Institutional Approaches. Acad. Manag. Rev. 1995, 20, 571-610. [CrossRef]

21. Granger, C.W.J. Investigating causal relations by econometric models and cross-spectral methods. Econometrica 1969, 37, 424-438. [CrossRef]

22. Jeucken, M.H.A.; Bouma, J.J. The changing environment of banks. Greener Manag. Int. 1999, 1999, $21-35$. [CrossRef]

23. Babiak, K.; Trendafilova, S. CSR and Environmental Responsibility: Motives and Pressures to Adopt Green Management Practices. Corp. Soc. Responsib. Environ. Manag. 2011, 18, 11-24. [CrossRef]

24. Scholtens, B. Corporate Social Responsibility in the International Banking Industry. J. Bus. Ethics 2008, 86, 159-175. [CrossRef]

25. Slager, R.; Chapple, W. Carrot and Stick? The Role of Financial Market Intermediaries in Corporate Social Performance. Bus. Soc. 2016, 55, 398-426. [CrossRef]

26. Francis, B.; Harper, P.; Kumar, S. The Effects of Institutional Corporate Social Responsibility on Bank Loans. Bus. Soc. 2018, 57, 1407-1439. [CrossRef]

27. Weber, O. Financial Sector Sustainability Regulations and Guidelines, in Encyclopedia of Business and Professional Ethicsl; Poff, D.C., Michalos, A.C., Eds.; Springer International Publishing: Cham, Germany, 2018; pp. 1-5.

28. Zeidan, R.; Boechat, C.; Fleury, A. Developing a Sustainability Credit Score System. J. Bus. Ethics. 2015, 127, 283-296. [CrossRef]

29. Weber, O.; Fenchel, M.; Scholz, R.W. Empirical analysis of the integration of environmental risks into the credit risk management process of European banks. Bus. Strategy Environ. 2008, 17, 149-159. [CrossRef]

30. Cerin, P.; Scholtens, B. Linking responsible investments to societal influence: Motives, assessments and risks. Sustain. Dev. 2011, 19, 71-76. [CrossRef]

31. Crifo, P.; Mottis, N. Socially Responsible Investment in France. Bus. Soc. 2016, 55, 576-593. [CrossRef]

32. Gond, J.-P.; Piani, V. Enabling Institutional Investors' Collective Action: The Role of the Principles for Responsible Investment Initiative. Bus. Soc. 2013, 52, 64-104. [CrossRef]

33. Furrer, B.; Hamprecht, J.; Hoffmann, V.H. Much Ado About Nothing? How Banks Respond to Climate Change. Bus. Soc. 2012, 51, 62-88. [CrossRef]

34. Chakroun, R.; Matoussi, H.; Mbirki, S. Determinants of CSR disclosure of Tunisian listed banks: A multi-support analysis. Soc. Responsib. J. 2017, 13, 552-584. [CrossRef]

35. Alberici, A.; Querci, F. The Quality of Disclosures on Environmental Policy: The Profile of Financial Intermediaries. Corp. Soc. Responsib. Environ. Manag. 2016, 23, 283-296. [CrossRef]

36. Igbudu, N.; Garanti, Z.; Popoola, T. Enhancing Bank Loyalty through Sustainable Banking Practices: The Mediating Effect of Corporate Image. Sustainability 2018, 10, 4050. [CrossRef]

37. Krause, K.; Battenfeld, D. Coming Out of the Niche? Social Banking in Germany: An Empirical Analysis of Consumer Characteristics and Market Size. J. Bus. Ethics 2017, 155, 889-911. [CrossRef]

38. Simpson, W.G.; Kohers, Y. The Link Between Corporate Social and Financial Performance: Evidence from the Banking Industry. J. Bus. Ethics 2002, 35, 97-109. [CrossRef]

39. Kobeissi, N.; Damanpour, F. Corporate responsiveness to community stakeholders: Effects of contextual and organizational characteristics. Bus. Soc. 2009, 48, 326-359. [CrossRef]

40. Shah, A.A.; Wu, D.; Korotkov, V. Are Sustainable Banks Efficient and Productive? A Data Envelopment Analysis and the Malmquist Productivity Index Analysis. Sustainability 2019, 11, 2398. [CrossRef]

41. Friede, G.; Busch, T.; Bassen, A. ESG and financial performance: Aggregated evidence from more than 2000 empirical studies. J. Sustain. Financ. Invest. 2015, 5, 210-233. [CrossRef] 
42. Qiu, J.; Movassaghi, H.; Bramhandkar, A. Socially conscious investing: Do good deeds get punished? Soc. Responsib. J. 2018, 14, 619-632. [CrossRef]

43. Climent, F. Ethical Versus Conventional Banking: A Case Study. Sustainability 2018, 10, 2152. [CrossRef]

44. Anagnostopoulos, T. Incorporating Sustainability Considerations into Lending Decisions and the Management of Bad Loans: Evidence from Greece. Sustainability 2018, 10, 4728. [CrossRef]

45. Prakash, A.; Kumar, K.; Srivastava, A. Consolidation in the Indian banking sector: Evaluation of sustainable development readiness of the public sector banks in India. Int. J. Sustain. Strateg. Manag. 2018, 6, 3-16. [CrossRef]

46. Risi, D. Time and Business Sustainability: Socially Responsible Investing in Swiss Banks and Insurance Companies. Bus. Soc. 2018, 59, 1410-1440. [CrossRef]

47. Kok, A.M.; De Bakker, F.G.A.; Groenewegen, P. Sustainability Struggles: Conflicting Cultures and Incompatible Logics. Bus. Soc. 2017, 58, 1496-1532. [CrossRef]

48. Chang, C.-H.; Sam, A.G. Corporate environmentalism and environmental innovation. J. Environ. Manag. 2015, 153, 84-92. [CrossRef] [PubMed]

49. Wang, X.; Lin, H.; Weber, O. Does Adoption of Management Standards Deliver Efficiency Gain in Firms' Pursuit of Sustainability Performance? An Empirical Investigation of Chinese Manufacturing Firms. Sustainability 2016, 8, 694. [CrossRef]

50. Sharma, S.; Vredenburg, H. Proactive Corporate Environmental Strategy and the Development of Competitively Valuable Organizational Capabilities. Strateg. Manag. J. 1998, 19, 729-753. [CrossRef]

51. van Kleef, J.A.G.; Roome, N.J. Developing capabilities and competence for sustainable business management as innovation: A research agenda. J. Clean. Prod. 2007, 15, 38-51. [CrossRef]

52. Darnall, N.; Carmin, J. Greener and cleaner? The signaling accuracy of U.S. voluntary environmental programs. Policy Sci. 2005, 38, 71-90. [CrossRef]

53. Rodriguez-Dominguez, L.; Gallego-Alvarez, I.; Garcia-Sanchez, I. Corporate Governance and Codes of Ethics. J. Bus. Ethics 2009, 90, 187-202. [CrossRef]

54. Thistlethwaite, J. Private governance and sustainable finance. J. Sustain. Financ. Invest. 2014, 4, 61-75. [CrossRef]

55. Weber, O. Financial Sector Sustainability Regulations and Voluntary Codes of Conduct: Do They Help to Create a More Sustainable Financial System? In Designing a Sustainable Financial System: Development Goals and Socio-Ecological Responsibility; Walker, T., Kibsey, S.D., Crichton, R., Eds.; Springer International Publishing: Cham, Germany, 2018; pp. 383-404.

56. Task Force on Climate-related Financial Disclosures. Task Force on Climate-related Financial Disclosures: Status Report; Task Force on Climate-related Financial Disclosures: Basel, Switzerland, 2018.

57. Battiston, S.; Mandel, A.; Monasterolo, I.; Schuetze, F.; Visentin, G. A climate stress-test of the financial system. Nat. Clim. Chang. 2017. [CrossRef]

58. Alguindigue, P.I. Macro-Prudential Implications of Sustainability Policies in the Banking Sector; University of Waterloo: Waterloo, ON, USA, 2020.

59. Zhao, N.; Xu, X.-J. Analysis on green credit in China. Adv. Appl. Econ. Financ. 2012, 3, 501-506.

60. Jiguang, L.I.U.; Zhiqun, S. Low Carbon Finance: Present Situation and Future Development in China. Energy Procedia 2011, 5, 214-218. [CrossRef]

61. Jin, D.; Mengqi, N. The paradox of green credit in China. Energy Procedia 2011, 5, 1979-1986. [CrossRef]

62. Mengze, H.; Wei, L. A Comparative Study on Environment Credit Risk Management of Commercial Banks in the Asia-Pacific Region. Bus. Strategy Environ. 2015, 24, 159-174. [CrossRef]

63. Nwafor, M.C. Impact of social banking on bank perfromance in Nigeria. Int. J. Res. Dev. 2018, 3, $2455-7838$.

64. Urban, M.A.; Wójcik, D. Dirty Banking: Probing the Gap in Sustainable Finance. Sustainability 2019, 11, 1745. [CrossRef]

65. Belal, A.R. Environmental reporting in developing countries: Empirical evidence from Bangladesh. Eco-Manag. Audit. 2000, 7, 114-121. [CrossRef]

66. Belal, A.R.; Roberts, R. Stakeholders' Perceptions of Corporate Social Reporting in Bangladesh. J. Bus. Ethics 2010, 97, 311-324. [CrossRef]

67. Belal, A.R.; Cooper, S. The absence of corporate social responsibility reporting in Bangladesh. Crit. Perspect. Account. 2011, 22, 654-667. [CrossRef] 
68. Sobhani, F.A.; Amran, A.; Zainuddin, Y. Sustainability disclosure in annual reports and websites: A study of the banking industry in Bangladesh. J. Clean. Prod. 2012, 23, 75-85. [CrossRef]

69. Masukujjaman, M.; Aktar, S. Green Banking in Bangladesh: A Commitment towards the Global Initiatives. J. Bus. Technol. 2014, 8, 17-40. [CrossRef]

70. Preston, L.E.; Post, J.E. Private Management and Public Policy; Prentice-Hall: Englewood Cliffs, NJ, USA, 1975.

71. Wright, C.; Nyberg, D. An inconvenient truth: How organizations translate climate change into business as usual. Acad. Manag. J. 2017, 60, 1633-1661. [CrossRef]

72. Patten, D.M. Exposure, legitimacy, and social disclosure. J. Account. Public Policy 1991, 10, 297-308. [CrossRef]

73. Porter, M.E.; Kramer, M.R. Strategy \& Society: The Link Between Competitive Advantage and Corporate Social Responsibility. Harv. Bus. Rev. 2006, 84, 78-92.

74. Weber, O.; Koellner, T.; Habegger, D.; Steffensen, H.; Ohnemus, P. The relation between sustainability performance and financial performance of firms. Prog. Ind. Ecol. 2008, 5, 236-254. [CrossRef]

75. Global Reporting Initiative. G4 Sustainability Reporting Guidelines; Global Reporting Initiative, Ed.; Global Reporting Initiative: Amsterdam, The Netherlands, 2013; p. 94.

76. Global Reporting Initiative. G4 Sector Disclosures-Financial Services; The Global Reporting Initiative: Amsterdam, The Netherlands, 2013.

77. Soana, M.-G. The Relationship Between Corporate Social Performance and Corporate Financial Performance in the Banking Sector. J. Bus. Ethics 2011, 104, 133-148. [CrossRef]

78. Hausman, J.A. Specification tests in econometrics. Econom. J. Econom. Soc. 1978, 1251-1271. [CrossRef]

79. Wu, C.F.J. Jackknife, Bootstrap and Other Resampling Methods in Regression Analysis. Ann. Stat. 1986, 14, 1261-1295. [CrossRef]

80. Cronbach, L.J. Coefficient alpha and the internal structure of tests. Psychometrika 1951, 16, 297-334. [CrossRef]

81. Dhaliwal, D.; Li, O.Z.; Tsang, A.; Yang, Y.G. Corporate social responsibility disclosure and the cost of equity capital: The roles of stakeholder orientation and financial transparency. J. Account. Public Policy 2014, 33, 328-355. [CrossRef]

82. Mardia, K.V. Assessment of Multinormality and the Robustness of Hotelling's T2. Test. J. R. Stat. Soc. Ser. C (Appl. Stat.) 1975, 24, 163-171.

83. Waddock, S.; Graves, S.B. The corporate social performance-financial performance link. Strateg. Manag. J. 1997, 18, 303-319. [CrossRef]

84. Englert, M.R.; Koch, C.; Wüstemann, J. The Effects of Financial Crisis on the Organizational Reputation of Banks: An Empirical Analysis of Newspaper Articles. Bus. Soc. 2019, 0007650318816512. [CrossRef]

85. Islam, M.T.; Kokubu, K. Corporate social reporting and legitimacy in banking: A longitudinal study in the developing country. Soc. Responsib. J. 2018, 14, 159-179. [CrossRef]

86. Weber, O. Environmental, Social and Governance Reporting in China. Bus. Strategy Environ. 2014, 23, 303-317. [CrossRef]

87. Weber, O.; Diaz, M.; Schwegler, R. Corporate Social Responsibility of the Financial Sector-Strengths, Weaknesses and the Impact on Sustainable Development. Sustain. Dev. 2014, 22, 321-335. [CrossRef]

88. McGuire, J.B.; Schneeweis, T.; Branch, B. Perceptions of Firm Quality: A Cause or Result of Firm Performance. J. Manag. 1990, 16, 167-180. [CrossRef]

89. Ullmann, A.A. Data in Search of a Theory: A Critical Examination of the Relationships among Social Performance, Social Disclosure, and Economic Performance of U. S. Firms. Acad. Manag. Rev. 1985, 10, 540-557.

90. Bapuji, H.; Husted, B.W.; Lu, J.; Mir, R. Value Creation, Appropriation, and Distribution: How Firms Contribute to Societal Economic Inequality. Bus. Soc. 2018, 57, 983-1009. [CrossRef]

91. Alamgir, F.; Alakavuklar, O.N. Compliance Codes and Women Workers' (Mis)representation and (Non)recognition in the Apparel Industry of Bangladesh. J. Bus. Ethics 2018. [CrossRef]

92. Busch, T.; Bauer, R.; Orlitzky, M. Sustainable Development and Financial Markets: Old Paths and New Avenues. Bus. Soc. 2015. [CrossRef]

(C) 2020 by the authors. Licensee MDPI, Basel, Switzerland. This article is an open access article distributed under the terms and conditions of the Creative Commons Attribution (CC BY) license (http://creativecommons.org/licenses/by/4.0/). 